\title{
Evaluation of the antibacterial activity of Borassus flabellifer male inflorescence against selected human pathogenic bacteria
}

\author{
S Vinujan $^{1}$, R Jalani ${ }^{2}$, S Srivijeindran ${ }^{1}$
}

Introduction and Objectives: The distribution of palmyrah (Borassus flabellifer) is confined to tropical and subtropical regionsof the world. This tree is well known for its commercial diversity products. In addition to common use, this work focused on the merit of male inflorescence (MI) of B. flabellifer towards growth-resistant activity against selected human pathogenic bacteria.

Methods: The in vitroantibacterial activity of the sample was evaluated by the agar well diffusion method. A methanol crude extract of oven-dried $\left(50{ }^{\circ} \mathrm{C}\right.$ for 3 days) MI was prepared using the soxhlet extraction process followed by evaporated using a rotary evaporator under reduced pressure at $45^{\circ} \mathrm{C}$. In this work, Escherichia coli (ATCC 35218), Staphylococcus aureus (ATCC 25923), Enterococcus faecalis (ATCC 29212), Salmonella enterica (ATCC 14028) were used. The appropriate number of $8 \mathrm{~mm}$ diameter wells were prepared and the average diameter of the inhibition zone was recorded from replicate measurements. The potential activity of the crude extract was compared with chloramphenicol at a concentration of $0.1 \mu \mathrm{g} / \mathrm{ml}$.

Results:Observations revealed that the tested two concentrations (100 and $200 \mathrm{mg} / \mathrm{ml}$ ) exhibited antibacterial effect against the tested bacterial cultures. The measured inhibition diameter at $100 \mathrm{mg} / \mathrm{ml}$ concentration for Escherichia coli, Staphylococcus aureus, and Enterococcus faecaliswas $11.4 \mathrm{~mm}, 11.8 \mathrm{~mm}$, and $12.2 \mathrm{~mm}$ respectively. At $200 \mathrm{mg} / \mathrm{ml}$ concentration, the inhibition zone diameters were $12.4 \mathrm{~mm}, 14.5 \mathrm{~mm}$, and $12.6 \mathrm{~mm}$ respectively. Salmonella entericaexhibited no inhibition at the tested two concentrations. The zone of inhibition for E. coli, S. aureus, E. faecalis, and S. enterica withchloramphenicol was $24.7 \mathrm{~mm}, 31.1 \mathrm{~mm}, 26.9 \mathrm{~mm}$, and $26.3 \mathrm{~mm}$ respectively.

Conclusions: There is potential growth inhibitory activity in the organic solvent extract of the male inflorescence of $B$. flabellifer against the tested bacteria. Further studies are required on the isolation and characterization of bioactive compounds responsible for this activity.

Keywords: Borassus flabellifer, medicinal importance, antimicrobial activity, well diffusion

\footnotetext{
${ }^{1}$ Palmyrah Research Institute, Palmyrah Development Board, Kandy Road, Kaithady, Jaffna, Sri Lanka ${ }^{2}$ Department of Biosystems Technology, Faculty of Technology, University of Sri Jayewardenepura,Sri Lanka 